UDC 378.041:78-057.87

DOI: $10.31866 / 2616-7581.2 .2018 .153379$

\author{
Yuliia Lebid, \\ Ph.D. in Pedagogy, Senior Teacher \\ of Music Department, \\ Kyiv National University \\ of Culture and Arts, \\ Kyiv, Ukraine \\ e-mail:yuliia.lebid@gmail.com \\ ORCID: https://orcid.org/0000-0001-6114-572X
}

\title{
THE EXPERIENCE OF SELF-REGULATION AS THE BASIS FOR THE MUSIC STUDENTS' SUCCESSFUL TRAINING
}

The contemporary system of specialists' professional training in the field of Musical Art as a priority task puts forward the training of a specialist capable of continuous self-development and self-improvement. Nowadays the demand for professional qualities is largely based on individual self-regulation mechanisms' activation. Thus, the study of pedagogical conditions' organization that will favour the development of student autonomy in educational, artistic and creative activities, as well as encourage future professionals to continuous self-development and selfimprovement, is determined by the practical needs of a contemporary system of training specialists in the field of Musical Art.

The comprehensive study of self-regulation mechanisms in specific types of human activity is the scientific basis that enables the solution of the strategic tasks of the contemporary educational system. Therefore, the increase of the effectiveness of the future musicians training through the creation of pedagogical conditions aimed at the development of professional skills and skills of self-regulation during the term of studying at a higher educational establishment, which is the purpose of our research, needs systematization of the data available related to the musical performance and educational activity in the coordinates of acquiring of individual self-regulation experience on the part of a personality. The logic of achieving this goal led to the choice of research methods: the critical analysis of scientific and methodological literature on the problem (to identify the degree of development and prospects for further exploration), methods of systematization and analogy (to identify specific features of self-regulation of musical performance in comparison with other activities), method of abstraction and modeling (for studying the structure of the phenomenon under investigation as an integrative entity, combining the components of the experience of the individual with the structural and the links of self-regulation as a process).

Depending on the type of activity and the conditions for its implementation, the self-regulation is realized by means of various mental methods, and the self-regulation skills of a certain type of activity forming the experience of specialist self-regulation, which has a unique structure that reflects the essential features of the professional activity type and the self-regulation individual of this activity. 
Since a personal entity formed as a result of the numerical strategies implementation for the achievement of a professionally significant goal, the experience of music students' self-regulation is a complex phenomenon that reflects the structural elements of self-regulation both as a process and structure of personal experience of the individual, on the one hand, and a result and basis of his professional activity, on the other hand, which is fixed in the system of knowledge, skills, emotional and value attitudes.

Conclusions. The process of gaining self-regulation experience in the frameworks of musical art is viewed as a process of the personality's entering into the spiritual universe of universal culture, is the basis and result of a professional self-actualization of a musician. Specific features of musical performance should be taken into account while creating pedagogical conditions for the formation of the student self-regulation experience.

Key words: self-regulation, experience, the development of student autonomy, system of training specialists in the field of Musical Art.

Introduction. The contemporary system of specialists' professional training in the field of Musical Art as a priority task puts forward the training of a specialist capable of continuous self-development and self-improvement in the profession chosen, a specialist capable of continuing his education throughout his/her professional life and flexible to changing circumstances while remaining effective. Formation of creative independence of higher educational institutions' students as the basis for their professional selfrealization is a priority task of the modern system of professional training of artistic personnel in the context of these tasks.

Nowadays demand for professional qualities is largely based on individual self-regulation mechanisms' activation: the ability to formulate goals independently, development and implementation of strategies for achieving professional goals, evaluation of the training and professional activities results, and the chosen strategies adjustment. In the context of this, the students' gaining of self-regulation experience in the process of studying at a higher educational institution is a condition for their successful professional development and effective entry into professional activities. Thus, the study of the organization of pedagogical conditions that will favour the development of student autonomy in educational and artistic and creative activities, as well as encourage future professionals to continuous self-development and self-improvement, is determined by the practical needs of a contemporary system of training specialists in the field of Musical Art.

Analysis of research and publications. The self-regulation phenomenon is widely outlined in the works by Soviet and Ukrainian scholars: S. L. Rubinstein, K. A. Abulkhanova-Slavskaya, A. V. Brushlinsky, A. V. Petrovsky, O. A. Konopkin, V. I. Morosanova. In the broadest sense, the term of self-regulation, which takes its origin from the Latin Regulare and being translated means "how to set up, debug", appears to be the mechanism that provides the expedient 
functioning of living systems of any level of organization and complexity. The psychic self-regulation is one of the levels of regulation of the systems' activity - information process, being implemented through the various mental forms of reality reflection. So self-regulation is viewed as a closed regulatory contour, and all the diversity of its manifestation is reduced to a structure that includes a model of meaningful working conditions, a program of executive actions, a system of criteria for the successful activity, information on the actually achieved results and the assessment of the correspondence of the actual results to the criteria for success, the decision on the correction of the activity (Konopkin, 2011).

Within the framework of the activity approach, which treats activity as the main source of the self-regulation formation and development, attention is drawn to a number of studies devoted to self-regulation in various kinds of professional activity. Thus, the self-regulation of pedagogical activity is highlighted in works by O. Belous, I. Halian, O. Dmitriceva, I. Zyazyun, G. Mashtakova, O. Pekhta, G. Sagach, N. Tarasevich, O. Shevchishin and others.

Traditionally, the problem of self-regulation skills formation is topical for the sphere of musical performance, where self-regulation is studied in the context of practical issues of overcoming stage emotions on the part of musicians, the search for psychological methods for getting ready to a concert performance, the emotional stability and performance reliability formation, the development of artistry as well (Yunyk, 2015). Prominent musicians-teachers, such as L. Bochkarev, G. Kogan, L. Makkinon, G. Niguaz devoted their attention to the mentioned issues; specialists in the field of musical psychology V. Petrushin, G. Tsipin, Y. Tsaggarelli. This urgent problem is now being studied by L. Kotova, G. Saik, O. Khlebnikova, D. Yunyk, T. Yunyk.

The self-regulation significance for a successful students academic activity is highlighted in the works by T. Borova, M. Grinev L. Derkach, V. Lyudys, O. Osnitsky, V. Spiwak. The researchers emphasize that "the result of selfregulation is the education of purposefulness, organization, ability to own" (Gruuneva, 2013, p.159) - such urgent and vital personal traits today.

The comprehensive study of the general self-regulation mechanisms of living systems and their manifestation in specific types of human activity is the scientific basis that enables the solution of the strategic tasks of the contemporary educational system. Therefore, the effectiveness increasing of the future musicians training through the creation of pedagogical conditions aimed at the development of professional skills and skills of self-regulation during the term of studying at a higher educational establishment, which is the purpose of our article, needs systematization of the data available related to the musical performance and educational activity in the coordinates of acquiring an of individual self-regulation experience on the part of a personality. 
The logic of achieving this goal led to the choice of research methods: the critical analysis of scientific and methodological literature on the problem (to identify the degree of development and prospects for further exploration substantiation of consideration of the development of self-regulation among musical students as a holistic process of acquiring an individual experience of self-regulation as the basis of their creative individuality), methods of systematization and analogy (to identify specific features of self-regulation of musical performance in comparison with other activities and to highlight the specifics of self-regulation of music students in musical performing and educational activities, which form the basis for the process of their professional training), method of abstraction and modeling (for studying the structure of the phenomenon under investigation as an integrative entity, combining the components of the experience of the individual with the structural and the links of self-regulation as a process).

Presentation of the main material: Ensuring the success of a particular type of activity, self-regulation itself is at the same time a higher-level mechanism that provides the individual self-realization and is essential for human life in society, since "in the process of converting external requirements into a controlled balance of the inner world, one creates his own experience of individual behavior of the individual". (Susoyeva, 2004, p.14).

Nowadays, self-realization and self-development are a prerequisite for the sustainability of psychological systems (Galyazhinsky, \& Klochko, 1999) in the changing conditions. The success of the professional training of music students is determined, including the degree of their readiness for real professional selfrealization, as well as to further professional self-development and selfimprovement throughout life (Artemova, 2014).

Depending on the type of activity and the conditions for its implementation, the self-regulation is realized by means of various mental methods, and the skills of self-regulation of a certain type of activity form the experience of selfregulation of a specialist, which has a unique structure that reflects the essential features of the of professional activity type and the individual style of selfregulation of this activity (Kisljakova, \& Zobnina, 2017).

The professional activity of a musician and the system of professional training of specialists-to-be in the field of musical art is concentrated around educational, cognitive and artistic and creative activities, and therefore, appeals to the cognitive and emotional spheres of the individual primarily. At the same time, the achievement of a personal and professional significant goal is impossible without updating the motivational-volitional resources. It is the will and the level of its development that characterizes the person's ability to mobilize intellectual and emotional efforts in the process of achieving the goal. Consequently, the integral nature of self-regulation manifests itself in the interconnection of emotions, will and intellect of a personality. 
As a personal entity formed as a result of the implementation of numerical strategies for the achievement of a professionally significant goal, the experience of music students' self-regulation is viewed as a system of interrelated components: the experience of emotional, intellectual and behavioral self-regulation.

Thus, self-regulation of intellectual activity is viewed as a process of conscious self-development of its own inborn and acquired intellectual features and is an important condition for gaining the experience of self-regulation of the music students' educational activity, implemented within the framework of the self-regulation path from the identification of the cognitive activity purpose, through the construction of a sequence of actions, an intermediate results and activities assessment regarding their correction. The behavior self-regulation is performed within the mentioned above contour - a process of conscious correction and situational modeling of educational and musical-performing activities. In our opinion, the emotional state self-regulation as the conscious correction of the emotional sphere reflection in the process of the musician's activity of other nature is determined by the character of the musical performance activity.

Taking into consideration the fact that musical art is the fundamental essential aspect of being a musician, it is important for our study to determine the nature of the musical phenomenon as embracing absolute values and universal human experience. Consequently, we can conclude that the process of gaining self-regulation experience in the frameworks of musical art is viewed as a process of the personality's entering into the spiritual universe of universal culture, the search for the highest sense of musical-performing activity in correlation with artistic values.

The self-regulating experience of the musician accumulates the knowledge, and skills accumulated as a result of life and professional activity that provide planning, forecasting and correction of the professional area and reflect the level of readiness of the individual to continuous self-education and self-development in the chosen field. The experience of self-regulation is a complex phenomenon that reflects the structural elements of self-regulation as a process and structure of individual experience of the individual, on the one hand, and a result and basis of his professional activity, on the other hand, which is fixed in the system of knowledge, skills, emotional and value attitudes. The source of gaining experience self-regulation on the part of music students is their music performing and music educational activity, and the experience implementation is aimed at the highest personal and professionally significant results.

Conclusions. Nowadays, self-regulation experience is viewed as the basis of the creative individuality of a specialist in the context of the topical challenges regarding the training of artistic personnel, providing continuous professional self-education and self-improvement. The experience of selfregulation, as an integral personal entity, is the basis and result of a professional 
self-actualization of a musician. Specific features of musical performance, its artistic and creative nature predetermine the specific character of the experience of self-regulation of specialists in the field of musical art and should be taken into account while creating pedagogical conditions for the formation of the student self-regulation experience, the practical study of which is the prospect of our study.

\section{References}

Artemova, O.I. (2010). Profesiina samorealizatsiia osobystosti v suchasnykh umovakh [Professional self-realization of the person in modern conditions]. Osvita rehionu: politolohiia, psykholohiia, komunikatsii, 1, 97. Retrieved from http://socialscience.com.ua/article/186 [in Ukrainian].

Hrynova, M. (2013). Samorehuliatsiia yak osnova uspishnoi navchalnoi diialnosti molodi [Self-regulation as the basis for successful youth education]. Problemy pidhotovky suchasnoho vchytelia, 8 (2), 159-163 [in Ukrainian].

Kislyakova, L.P., \& Zobnina, T.V. (2017). Issledovanie vzaimosvyazi sposobnosti $\mathrm{k}$ samoregulyatsii deyatelnosti i motivatsii dostizheniy, silyi voli, tvorcheskogo potentsiala lichnosti studentov - buduschih pedagogov [Investigation of the interconnection of the ability to self-regulate activities and motivate achievements, willpower, creative potential of the personality of students - future educators]. Sovremennyie issledovaniya sotsialnyih problem, 8, (8), 99-111. doi: https://doi.org/10.12731/2218-7405-2017-8-99-111 [in Russian].

Klochko, V.E., \& Galazhinskiy, E.V. (1999). Samorealizatsiya lichnosti: sistemnyiy vzglyad [Self-realization of personality: a systemic view]. Tomsk: Izdatelstvo Tomskogo universiteta [in Russian].

Konopkin, O.A. (2011). Psihologicheskie mehanizmyi regulyatsii deyatelnosti [Psychological mechanisms of regulation of activity] [Monograph] (2nd ed.). Moscow: Lenand [in Russian].

Sysoieva, S.O. (2000). Problema formuvannia osobystosti, zdatnoi do tvorchoi samorealizatsii [The problem of forming a person capable of creative selfrealization]. Naukovi pratsi: Pedahohika, 1 (7), 13-19 [in Ukrainian].

Yunyk, D.H. (2015). Samokorektsiia vykonavskoi diialnosti muzykantivinstrumentalistiv [Self-correction of performances of instrumental musicians]. Naukovyi chasopys Natsionalnoho pedahohichnoho universytetu imeni M.P. Drahomanova, Seriia 14: Teoriia i metodyka mystetskoi osvity, 17 (22), 15-20 [in Ukrainian].

(C) Lebid Yu., 2018 


\author{
Юлія Лебідь, \\ кандидат педагогічних наук, \\ стариий викладач \\ кафедри музичного мистецтвва, \\ Київський національний університет \\ культури і мистецтвв, \\ Київ, Україна \\ e-mail: yuliia.lebid@gmail.com \\ ORCID: https://orcid.org/0000-0001-6114-572X
}

\section{ДОСВІД САМОРЕГУЛЮВАННЯ ЯК ОСНОВА УСПІШНӦ̈ ПРОФЕСІЙНӦ̈ ПІДГОТОВКИ СТУДЕНТІВ-МУЗИКАНТІВ}

Пріоритетним завданням сучасної системи професійної підготовки фахівців у галузі музичного мистецтва $є$ підготовка спеціалістів, здатних до безперервного саморозвитку та самовдосконалення в обраній професії. Затребувані сьогоденням професійні якості значною мірою грунтуються на активізації механізмів саморегуляції особистості. Набуття студентами досвіду саморегулювання в процесі навчання у вищому мистецькому навчальному закладі постає умовою їхнього успішного професійного становлення та ефективного входження в професійну діяльність.

Всебічне вивчення феномена саморегуляції є тим науковим підгрунтям, що уможливлює вирішення стратегічних завдань сучасної системи освіти. Відтак підвищення ефективності професійної підготовки майбутніх музикантів шляхом створення педагогічних умов для розвитку умінь і навичок саморегуляції в ході навчання у вищому мистецькому навчальному закладі, що $\epsilon$ метою цього дослідження, потребує систематизації наявних даних стосовно музичновиконавської та навчальної діяльності в координатах набуття студентами індивідуального досвіду саморегулювання. Логіка досягнення зазначеної мети зумовила вибір методів дослідження: критичний аналіз наукової та методичної літератури з проблеми (для виявлення ступеня розробленості та перспективи подальших розвідок), методи систематизації та аналогії (для виявлення специфічних особливостей саморегуляції музично-виконавської діяльності в порівнянні 3 іншими видами діяльності), методи абстрагування та моделювання (для вивчення структури досліджуваного феномена як інтегративного утворення, що поєднує компоненти досвіду особистості із структурними ланками саморегуляції як процесу).

Залежно від виду діяльності та умов ¥іi здійснення саморегуляція здійснюється різними психічними засобами, а навички саморегуляції певного виду діяльності складаються у досвід саморегулювання фахівця, що має унікальну структуру, яка віддзеркалює сутнісні особливості виду професійної діяльності та індивідуальний стиль саморегулювання цієї діяльності.

Як особистісне утворення, що формується в результаті реалізації чисельних стратегій досягнення професійнозначущої мети, досвід саморегулювання постає складним феноменом, що віддзеркалює структурні ланки саморегуляції як процесу та структури індивідуального досвіду особистості як результату 
й основи його професійної діяльності, закріпленої в системі знань, умінь, навичок та емоційно-ціннісних ставлень.

Висновки. Набуття досвіду саморегулювання в координатах музичного мистецтва $\epsilon$ процесом уходження особистості до духовного універсуму загальнолюдської культури та основою й результатом професійної самореалізації музиканта. Специфічні особливості музично-виконавської діяльності зумовлюють своєрідність досвіду саморегулювання фахівців у галузі музичного мистецтва і повинні враховуватися у створенні педагогічних умов для його формування.

Ключові слюва: саморегуляція, досвід, студенти-музиканти, професійна підготовка.

УДК 378.041:78-057.87

\author{
Юлия Лебидь, \\ кандидат педагогических наук, \\ стариий преподаватель \\ кафедры музыкального искусства, \\ Киевский национальный университет \\ культуры и искусств, \\ Киев, Украина \\ e-mail: yuliia.lebid@gmail.com \\ ORCID: https://orcid.org/0000-0001-6114-572X
}

\title{
ОПЫТ САМОРЕГУЛИРОВАНИЯ КАК ОСНОВА УСПЕШНОЙ ПРОФЕССИОНАЛЬНОЙ ПОДГОТОВКИ СТУДЕНТОВ-МУЗЫКАНТОВ
}

Приоритетной задачей современной системы профессиональной подготовки специалистов сферы музыкального искусства является подготовка специалистов, способных к непрерывному саморазвитию и самосовершенствованию в выбранной профессии. Актуальные в контексте современных требований профессиональные качества в значительной мере основываются на активизации механизмов саморегуляции личности. Приобретение студентами опыта саморегулирования в процессе обучения в вузе является сегодня одним из условий их успешного профессионального становления и эффективного вхождения в профессиональную деятельность.

Всестороннее изучение феномена саморегуляции является той научной базой, которая делает возможным решение стратегических задач современной системы образования. Соответственно повышение эффективности профессиональной подготовки будущих музыкантов путем создания педагогических условий для развития умений и навыков саморегулирования, что является целью этого исследования, требует систематизации имеющихся данных относительно музыкально-исполнительской и учебной деятельности в координатах приобретения студентами индивидуального опыта саморегулирования. Логика достижения указанной цели обусловила выбор методов 
исследования: критический анализ научной и методической литературы по проблеме (для выявления степени разработанности проблемы и перспектив дальнейшего исследования), методы систематизации и аналогии (для выявления специфических особенностей саморегуляции музыкально-исполнительской деятельности в сравнении с другими видами деятельности), методы абстрагирования и моделирования (для изучения структуры исследуемого явления, как интегративного образования, которое объединяет компоненты опыта личности со структурными звеньями саморегуляции как процесса).

В зависимости от вида деятельности и условий ее осуществления саморегуляция реализуется различными психическими способами, а навыки саморегуляции определенного вида деятельности складываются в опыт саморегулирования, который имеет уникальную структуру, отражающую существенные особенности вида профессиональной деятельности и индивидуальный стиль саморегуляции этой деятельности.

Как личностное образование, формирующееся в результате реализации многочисленных стратегий достижения профессиональнозначимой цели, опыт саморегулирования является сложным феноменом, который отражает структурные звенья саморегуляции как процесса и структуры индивидуального опыта личности как результата и основы его профессиональной деятельности, закрепленной в системе знаний, умений, навыков и эмоционально-ценностных отношений.

Выводы. Приобретение опыта саморегулирования в координатах музыкального искусства является процессом вхождения личности в духовный универсум общечеловеческой культуры, основой и результатом профессиональной самореализации музыканта. Специфические особенности музыкально-исполнительской деятельности обуславливают своеобразие опыта саморегулирования специалистов в области музыкального искусства и должны учитываться в создании педагогических условий для его формирования.

Ключевые слова: саморегуляция, опыт, студенты-музыканты, профессиональная подготовка. 